Research Article

\title{
Serum Level of Anti-Hepatitis B Surface Antigen 18 Years after Vaccination in Students of Golestan University of Medical Sciences, Iran
}

\author{
Rokhsare Ebneghasem $^{1}$ (D) , Sima Besharat ${ }^{2}$ (D), Behnaz Khodabakhshi ${ }^{1}$ (D), Roghieh \\ Golsha $^{1}$ (D), Hessamaddin Shirzad-Aski ${ }^{1}$ (D), Ahmad Sohrabi ${ }^{1}$, Khadije Amjadi ${ }^{1}$, Souhail
} Meftah $^{3}$ (D) , Mina Niazi ${ }^{4}$ (D), Naghimeh Hajimoradloo ${ }^{1}$

1.Infectious Diseases Research Center; Golestan University of Medical Sciences, Gorgan, Iran

2.Golestan Research Center of Gastroenterology and Hepatology (GRCGH); Golestan

University of Medical Sciences, Gorgan, Iran.

3.Department of Electrical and Computer Engineering, National University of Singapore,

Singapore

4.Biomedical engineering department, National University of Singapore, Singapore

*Correspondence: Naghimeh Hajimoradloo, Infectious Diseases Research Center, Golestan

University of Medical Sciences, Gorgan, Iran

Tel: +989113712757

Email: N.hajimoradloo@yahoo.com

Received February 15, 2021

Accepted April 20, 2021

\begin{abstract}
Background and objectives: Hepatitis B virus (HBV) is one of the most common viral infections and amongst the top health priorities worldwide. Due to frequent exposure, medical students are at high risk of developing HBV infection. This study was conducted to evaluate serum level of anti-HBV surface antigen (HBsAg) 18 years after HBV vaccination in students of the Golestan University of Medical Sciences (Gorgan, Iran).
\end{abstract}

Methods: In this cross-sectional study, 241 students (18-20 years old, 137 women) who had been vaccinated at infancy were enrolled. After recording demographic data, blood sample was taken to measure $\mathrm{HBsAg}$, HBs anti-body (HBs-Ab) and $\mathrm{HBc}$ antibody (total $\mathrm{HBcAb}$ ) using commercial enzyme-linked immunosorbent assay kits. Data were analyzed by the chi-square test using SPSS 16 and at significance of 0.05 .

Results: HBsAb titer of less than $10 \mathrm{mlU} / \mathrm{ml}$ was found in 167 (69.3\%) participants (89 females and 78 males). Positive HBsAg and anti-HBcAb were not observed in the subjects. There was no significant relationship between antibody titer and sex, body mass index, place of residence and ethnicity $(\mathrm{P}>0.05)$.

Conclusion: The high number of medical students with seronegative antibody levels is a cause for concern. In this regard, more attention should be paid to high risk students in medical school of the Golestan Province.

Keywords: Hepatitis B virus, HBs antibody, vaccination.

\section{DOI: 10.29252/Jcbr.5.1.31}

\section{(c) (1) (3)}

This work is licensed under a Creative Commons Attribution 4.0 License.

(C) The authors 


\section{INTRODUCTION}

Hepatitis B infection is a major health problem worldwide (1). Around two billion people in the world have hepatitis $\mathrm{B}$, and more than 350 million people suffer from chronic hepatitis B, who mostly live in the Southeast Asia (2, $\underline{3})$. Each year, at least 800,000 people die from hepatitis B virus (HBV) infection and its complications. The virus accounts for $70-80 \%$ of chronic hepatitis incidents, which are the most common cause of liver disease and the leading cause of HBV-associated mortality. This virus is also the most important cause of fulminant hepatitis in Iran (4). The World Health Organization (WHO) has categorized the world into three epidemiological regions in terms of $\mathrm{HBV}$ prevalence: prevalence of less than $2 \%$, moderate prevalence $(2-8 \%)$ and high prevalence (more than 8\%) (ㅁ). The average prevalence of the disease is currently $2.2 \%$ in Iran; however, the Golestan Province has a higher prevalence rate $(8.9 \%)$ compared to the national average rate in Iran ( $\underline{6})$.

Currently, the best way to control and prevent the disease is to use HBV vaccines (7). According to the WHO recommendation, all infants should receive hepatitis B vaccine right after birth, preferably within 24 hours. In Iran, the national hepatitis $B$ vaccination program has been implemented since 1993 for infants and high-risk groups. Complete vaccination increases the antibody levels in over $95 \%$ of infants, children and adults ( $\underline{8})$. Immunity against this disease is assessed by measuring the serum level of antibody against the hepatitis B surface antigen (HBsAb). Values equal to or greater than $10 \mathrm{mlU} / \mathrm{ml}$ indicate immunity (7). Various studies have shown that the antibody titer decreases over time $(\underline{9}, \underline{12}-14)$. On the other hand, numerous studies have shown that $1-10 \%$ of apparently healthy individuals cannot produce antibodies at acceptable levels after vaccination, probably due to genetic factors, immunity suppression and certain diseases
(10). Medical students are among the people at risk of developing hepatitis B infection. Needle stick injury and contact with patient's mucosal surfaces are the main routs of HBV transmission (11). Given the lack of knowledge about HBV immunity in medical students in the Golestan Province, this study was conducted to evaluate the level of immunity against HBV among 2018-intake medical students.

\section{MATERIALS AND METHODS}

Based on previous data and considering a confidence interval of $95 \%$ and an accuracy of 0.06 , the sample size of the present study was calculated as 238 individuals (10). Accordingly, this descriptive cross-sectional study was conducted on 241 (137 men and 104 women) aged 18-20 years who were studying medicine, dentistry, nursing, paramedicine and midwifery at the Golestan University of Medical Sciences, Gorgan, Iran. Informed written consent was obtained from the participants, and the study protocol was approved by the ethics committee of the university (ethics code: IR. GOMUS.REC.1397.089). Participants completed a data collection form on age, sex, place of residence, body mass index (BMI) and ethnicity.

Blood samples were taken from the volunteers and kept at $-20{ }^{\circ} \mathrm{C}$ after separating the serum. Each sample was tested for $\mathrm{HBsAb}, \mathrm{HBsAg}$ and $\mathrm{HBcAb}$ (total) using commercial enzyme-linked immunosorbent assay kits (DIAPRO Inc., Italy). A serum level of $\mathrm{HBsAb}$ equal to or greater than $10 \mathrm{mlU} / \mathrm{ml}$ indicated immunity.

Based on the results, the subjects were divided into two groups of seropositive and seronegative. Data were analyzed with descriptive statistics using the Chi-square test. All statistical analyses were performed using SPSS 16 software and at significance level of 0.05 . 


\section{RESULTS}

All participants had received HBV vaccine during infancy according to the national vaccination program. Among the participants, 167 (69.3\%) had HBsAb level of less than $10 \mathrm{mIU} / \mathrm{ml}$ and were therefore classified as susceptible, while only 74 (30.7\%) subjects had antibody level of above $10 \mathrm{mIU} / \mathrm{ml}$. The distribution of $\mathrm{HBsAb}$ titers relative to sex, place of residence, BMI and ethnicity is presented in table 1. There was no significant relationship between the variables and the HBsAb level $(\mathrm{P}>0.05)$. Furthermore, all participants had negative $\mathrm{HBsAg}$ and $\mathrm{HBc}$ $\mathrm{Ab}$ (in total).

Table 1. Frequency distribution of HBsAb titers by sex, place of residence, BMI and ethnicity

\begin{tabular}{|c|c|c|c|c|c|}
\hline \multicolumn{2}{|c|}{ Variable } & HBsAb $<10(\%)$ & HBsAb $\geq 10(\%)$ & Total & P-value \\
\hline Sex & $\begin{array}{c}\text { Male } \\
\text { Female }\end{array}$ & $\begin{array}{l}78(75) \\
89(65)\end{array}$ & $\begin{array}{l}26(25) \\
48(35)\end{array}$ & $\begin{array}{l}104 \\
137\end{array}$ & 0.094 \\
\hline $\begin{array}{c}\text { Place of } \\
\text { residence }\end{array}$ & $\begin{array}{l}\text { Urban } \\
\text { Rural } \\
\end{array}$ & $\begin{array}{c}148(69.2) \\
19(70.4) \\
\end{array}$ & $\begin{array}{c}66(30.8) \\
8(29.6)\end{array}$ & $\begin{array}{c}214 \\
27 \\
\end{array}$ & 0.898 \\
\hline BMI & $\begin{array}{l}\text { Underweight } \\
\text { Normal } \\
\text { Overweight } \\
\text { Obese }\end{array}$ & $\begin{array}{c}22(68.8) \\
101(68.7) \\
28(70) \\
12(87.5)\end{array}$ & $\begin{array}{c}10(31.3) \\
46(31.3) \\
12(30) \\
2(14.3)\end{array}$ & $\begin{array}{c}32 \\
147 \\
40 \\
14\end{array}$ & 0.618 \\
\hline Ethnicity & $\begin{array}{c}\text { Persian } \\
\text { Turkman } \\
\text { Others } \\
\end{array}$ & $\begin{array}{l}113(68.9) \\
31(63.3) \\
23(82.1) \\
\end{array}$ & $\begin{array}{l}51(31.1) \\
18(36.7) \\
\circ 5(17.9) \\
\end{array}$ & $\begin{array}{c}164 \\
49 \\
28 \\
\end{array}$ & 0.221 \\
\hline
\end{tabular}

\section{DISCUSSION}

The results of this study indicated that a high proportion of people who had received HBV vaccination according to the national vaccination program had low serum levels of HBsAb (less than $10 \mathrm{mIU} / \mathrm{ml}$ ). Various studies have shown that vaccine-dependent antibody levels decrease or become immeasurable years after vaccination, which is consistent with this study (12-17). It seems that anti-HBsAb levels will drop in the first few years after vaccination, and one-third to half of the vaccinated children may have a titer of less than $10 \mathrm{IU} / \mathrm{L}$ at the age of 10 to 15 years $(\underline{12}, \underline{13})$. Environmental factors, infant age, type and dose of vaccine and vaccination intervals in each country can affect the serum levels of antibodies and the level of serum protection in individuals (18). Some previous studies showed that despite the continuous decline, antibody levels can remain at a protective level for a long time $(\underline{7}, \underline{18})$, which is inconsistent with this study. Other previous works have shown that $1-10 \%$ of apparently healthy individuals are unable to produce antibody after vaccination $(\underline{10}, \underline{20})$. Results vary in this regard, which is most likely due to genetic factors and difference in geographical features $(\underline{7}, \underline{10})$.

There was no significant relationship between gender and antibody titers, which is consistent with the results of previous studies (16, 20-22). However, some other studies reported a role for gender in increasing antibody titers $(\underline{5}, \underline{10}, \underline{23}-\underline{27})$. The inconsistency in the results could be due to the difference in study methods, antibody titer measurement, sample storage conditions before tests, sensitivity and specificity of kits used for the measurements, age of the study population and time of first vaccination. In our work, there was also no significant relationship between antibody level and place of 
residence, which is consistent with urban studies (28).

Considering the lack of an immune system response to $\mathrm{HBV}$ in some individuals and the decrease of vaccine-dependent antibody levels over time, the limitations of this study included the lack of knowledge of the immune response of participants after neonatal vaccination. One of the strengths of this study is the evaluation of markers of infection (anti-HBcAb and HBsAg) and the evaluation of antibodies (anti-HBsAb) in people with dispersed places of residency. Since HBsAg and $\mathrm{HBcAb}$ are markers of HBV infection, a negative result indicates no infection in our study subjects.

\section{CONCLUSION}

Due to the low levels of immunity against HBV in two-thirds of our subjects, injection of a HBV vaccine in the non-immune group is recommended. In addition, because students in different medical fields are exposed to $\mathrm{HBV}$, it seems necessary to evaluate HBsAb titer in all students upon admission to the university. It is also recommended to measure $\mathrm{HBsAb}$ titers several months after vaccination to evaluate the response to vaccine.

\section{ACKNOWLEDGMENTS}

The authors hereby express their gratitude to the Deputy of Research and Technology of Golestan University of Medical Sciences and all those who contributed generously to this research.

\section{DECLARATIONS \\ Funding}

The study has been supported by the Golestan University of Medical Sciences, Iran.

\section{Ethics approvals and consent to participate}

The study was approved by the ethics committee of Golestan University of Medical Sciences, Gorgan, Iran (ethics code: IR. GOMUS.REC.1397.089). A written informed consent was obtained from all subjects prior to participation.

\section{Conflict of interest}

The author declares that there is no conflict of interest regarding publication of this article.

\section{REFERENCES}

1. Asghari Estiar M, Moaddab R, Esmaeelnasab N, Rafi A. Immunogenicity of Hepatitis B Vaccine among Medical Staff of Shahid Madani Hospital of Tabriz, Iran. J Fasa Univ Med Sci. 2014; 4(2): 154-160. [In Persian] [View at Publisher] [Google Scholar]

2. Alavian SM, Hajarizadeh B, AhmadzadAsl M, Kabir A, Bagheri-Lankarani K. Hepatitis BVirus infection in Iran: A systematic review. Hepatitis monthly. 2008 Oct 1; 8. [View at Publisher] [Google Scholar]

3. Alavian SM, Fallahian F, Bagheri Lankarani K. The Changing Epidemiology of Viral Hepatitis B in Iran. J Gastrointestin Liver Dis. 2007; 16 (4): 403-406. [View at Publisher] [PubMed] [Google Scholar]

4. Berati M, Ishaqi M, Borji S. The level of knowledge of Mashkin-dasht students in Karaj about the ways of transmission and prevention of hepatitis B. Journal of Iran University of Medical Sciences. 2005; 12(46): 249-253. [Google Scholar]

5. Mohammad Nejad E, Ehsani SR, Rahmani H, Abootalebi Gh, Ranjbaran S, Zebardast J. Evaluation of Hepatitis B Virus Antibody and Effective Factors on its Changes in Nurses. JHC. 2012; 14(1 And 2): 36-43. [In Persian]. [View at Publisher] [Google Scholar]

6. Mostafa Salehi-Vaziri, Farzin Sadeghi, Amir Almasi Hashiani, Mohammad Gholami Fesharaki, Seyed Moayed Alavian. Hepatitis B Virus Infection in the General Population of Iran: An Updated Systematic Review and Meta-Analysis. Hepat Mon. 
2016; 16 (4): e35577. [View at Publisher] [DOI] [PubMed] [Google Scholar]

7. Taghavi Ardakani A, Soltani B Sharif MR, Moosavi GhA, Khademian M. Evaluation of serum hepatitis B antibody level in vaccinated children after 14 years in Kashan, Iran. Journal of Gorgan University of Medical Sciences. 2012; 14(3). [View at Publisher] [Google Scholar]

8. Hepatitis B. http://www.who.int/newsroom/fact-sheets/detail/hepatitis-B.

9. Jafarzadeh A, Montazerifar SJ. Persistence of anti-HBs antibody and immunological memory in children vaccinated with hepatitis $B$ vaccine at birth. J Ayub Med Coll Abbottabad. 2006; 18:4-6. [PubMed] [Google Scholar]

10. Nooshiravanpour P, Ramazenkhani A, Gashani M, Khodakarim S, Hatami H. Immunity against hepatitis-B among freshman students at Shahid Beheshti University of Medical Sciences, academic year 2012-2013. Research in Medicine. 2014; 38 (3):176-180. [View at Publisher] [Google Scholar]

11. Alavian SM, Tabatabaei SV, Nourizad $\mathrm{S}$, MansoriF , Khademi $\mathrm{N}$ and et al. Seroepid- emiology of HBV infectionin Kermanshah- west of Iran; a population based study. Jundishapour J Microbiol. 2012; 5 (4): 564-569. [View at Publisher] [DOI] [Google Scholar]

12. Shamsizadeh A, Makvandi M, Shoshtari G. Prevalence of anti-hepatitis B surface antibody among children in Ahvaz, Iran, five years after vaccination. JJM. (2011); 4(1): 49-54. [View at Publisher] [Google Scholar]

13. Norouzirad R; Shakurnia AH; Assarehzadegan MA; Serajian A; Khabazkhoob M. Serum Levels of AntiHepatitis B Surface Antibody Among Vaccinated Population Aged 1 to 18 Years in
Ahvaz City Southwest of Iran. Hepat Mon. 2014; 14(1). [View at Publisher] [DOI] [PubMed] [Google Scholar]

14. Lu CY, Chiang BL, Chi WK, Chang $\mathrm{MH}$, Ni YH, Hsu HM, et al. Waning immunity to plasma-derived hepatitis B vaccine and the need for boosters 15 years after neonatal vaccination. Hepatology. 2004; 40:1415-20. [View at Publisher] [DOI] [PubMed] [Google Scholar]

15. Amini S, Andalibi S, Mahmoodi M. Anti-HBs response and its protective effect in children and adults receiving hepatitis B recombinant vaccine in Tehran. Iranian $\mathbf{J}$ Med Sci. 2002; 27: 101-105. [View at Publisher] [Google Scholar]

16. Darvish Moghaddam S, Zahedi MJ, Yazdani R. Persistence of immune response after hepatitis vaccination in medical students and residents. Arch Iranian Med. 2004; 7:37-40. [View at Publisher] [Google Scholar]

17. Mahallawi W. Persistence of hepatitis $B$ surface antibody and immune memory to hepatitis B vaccine among medical college students in Madinah. Ann Saudi Med. 2018; 38(6): 413-419. [View at Publisher] [DOI] [PubMed] [Google Scholar]

18. Norrozi M, Azami A, Sarraf-neduad A, Chitsaz H, Rahmati. Persistence of anti-HBs antibody and immune memory to hepatitis B vaccine, 18 years after infantile vaccination in students of Tehran University. Research on Medicine; 2016; 40(1):36-41. [View at Publisher] [Google Scholar]

19. Kazemi A, Koosha A, Rafizadeh B, Mousavinasab N, Mahram M. Serum level of anti-hepatitis B surface antigen 6-8 years after hepatitis B vaccination at birth. East Mediterr Health J. 2008; 14:960-65.12. [View at Publisher] [PubMed] [Google Scholar]

20. Izadpanah A, Mashreghy Moghadam H, Ziaee M, Foadaldini M, Ebadian F. Anti 
HBs level in nursing staff of Birjand University of Medical Sciences. Journal of Birjand University of Medical Sciences. 2008; 15:80-85. [View at Publisher] [Google Scholar]

21. Rostami H, Farmani S, Mirzaee A, Ghorbanzadeh R. Evaluating the rate of immune response for hepatitis $b$ vaccine in high risk personel. J Urmia Nurs Midwifery Fac. 2008; 6 (4):179-182. [In Persian] . [View at Publisher] [Google Scholar]

22. Baba Mahmoodi F. Evaluation of Hepatitis B Antibody (HBS) Levels in Nursing Staff of Gaemshahr Razi Hospital and its Variation With Duration Of Immunity Post HB Vaccination. J Mazandaran Univ Med Sci. 2000; 10 (27):48-53.[In Persian]. [View at Publisher] [Google Scholar]

23. Mansour-Ghanaei F, Fallah MS, Jafarshad R, Joukar F, Arami A, Ale-esmaeil $\mathrm{F}$, et al. The Immunologic Response to antihepatitis $\mathrm{B}$ vaccination among medical students of Guilan University of Medical Sciences, Guilan, Iran.Hepatitis Monthly 2006; 6: 63-66. [View at Publisher] [Google Scholar]

24. Davoud-zadeh M, Rajabi poor F,
Shafi-zadeh F, Ghorbani vagheie A. Determination of HbsAb level in vaccinized medical students of Lorestan University of Medical Sciences in autumn 2004. Yafte. 2005; 6 (4):57-61. [In Persian]. [View at Publisher] [Google Scholar]

25. Shin BM, Jeong KW.Distribution of anti-HBs levels in Korean adults. Yonsei Medical Journal.2000; 41(1): 40-8. [View at Publisher] [DOI] [PubMed] [Google Scholar]

26. Funderburke PL, Spencer L. Hepatitis B immunity in high risk health care workers. Seven Years post vaccination. American Association of Occupational Health Nurses Journal.2000; 48(7):325-30. [View at Publisher] [DOI] [PubMed] [Google Scholar]

27. Hajibagheri K, Kanani Sh, Moradi Gh , Yousefinejad V. Response to Hepatitis B Vaccination among Health CcareWorkers .IJIDTM Journal.2008;13(40).[In Persian] [Google Scholar]

28. Shahri L, Ali Asghari F,et al. Evaluation of immune response of hepatitis $B$ vaccine in female students of North Khorasan University of Medical Sciences. Journal of North Khorasan University of Medical Sciences. 2013; 5: 1057-106. [View at Publisher] [DOI] [Google Scholar]

How to Cite: Ebneghasem R, Besharat S, Khodabakhshi B, Golsha R, Shirzad-Aski H, Sohrabi A, et al . Serum Level of Anti-Hepatitis B Surface Antigen 18 Years after Vaccination in Students of Golestan University of Medical Sciences, Iran. Journal of Clinical and Basic Research. 2021; $5(1): 31-36$. 